\title{
A new species of the endemic Australian genus Roscidotoga Hoare from rainforests in southern Queensland (Lepidoptera: Nepticulidae)
}

\author{
Erik J. van Nieukerken, Cornelis van den Berg \& Robert J. B. Hoare
}

\begin{abstract}
The new species Roscidotoga lamingtonia is described, a leafminer on Sloanea woollsii (Elaeocarpaceae) from the subtropical rainforests of Lamington National Park, southern Queensland, and Border Ranges National Park, New South Wales. $R$. callicomae Hoare, 2000 is recorded for the first time from Queensland, and from Lamington National Park. These records fall within the genus' limited range in the rainforests in eastern Australia. $R$. lamingtonia is the second species of the genus feeding on Elaeocarpaceae. On the basis of a few possible apomorphies we hypothesize one host-shift from Cunoniaceae to Elaeocarpaceae. DNA barcodes for $R$. lamingtonia and $R$. callicomae are given.

E.J. van Nieukerken* \& C. van den Berg, Netherlands Centre for Biodiversity Naturalis, PO Box 9517, 2300 RA Leiden, The Netherlands. nieukerken@naturalis.nl R.J.B. Hoare, Landcare Research Ltd., Private Bag 92-170, Auckland, New-Zealand. hoarer@landcareresearch.co.nz
\end{abstract}

\section{Introduction}

The discovery of the genus Roscidotoga Hoare, 2000, the most recently named genus in the Nepticulidae, was one of the big surprises during the study of the large diversity of Australian Nepticulidae for RJBH's thesis. The genus is sister to the other endemic Australian genus, Pectinivalva Scoble, 1982, and together these genera form the subfamily Pectinivalvinae. Monophyly of this subfamily was clearly demonstrated by morphology (Hoare 2000) and is also supported by the analysis of nuclear and mitochondrial DNA (Van Nieukerken et al. in prep.).

The three known species of Roscidotoga were collected in rainforests in Tasmania, New South Wales and southern Queensland. All feed on members of the angiosperm order Oxalidales, in contrast to the sister genus Pectinivalva, which is almost completely monophagous on Myrtaceae and has its largest diversity in the dry and seasonal eucalypt forests.

The area of northern New South Wales and southern Queensland has some of the best preserved and largest subtropical rainforests of Australia, and species of this genus were particularly expected in that region. To search for these and other Nepticulidae, two of us (RJBH and CVDB) organised a collecting expedition in the winter of 2000 (early July). In Lamington National Park they indeed found mines of possible Roscidotoga on black wattle Callicoma serratifolia Andrews (Cunoniaceae) and yellow carabeen Sloanea woollsii F. Muell. (Elaeocarpaceae), the latter were also found in Border Ranges National Park (NSW). Unfortunately rearing of the larvae failed, although some dead pupae reared from Sloanea appeared to contain full-grown adults and study of their genitalia showed they belonged to Roscidotoga. The senior author visited the Lamington National Park in August 2004 on the occasion of the International Congress of Entomology in Brisbane, and was able to find larvae again of both species, and more specimens were found a week later together with RJBH. Two reared males allow us now to describe this species and supplement the original description of the genus (Hoare 2000). 


\section{Material and methods}

For most methods we refer to Hoare (2000). Rearing was carried out in the Netherlands. The pupae were kept with some moss in small plastic containers with lids, in a breeding cabinet with artificial TL light and temperatures regulated to imitate the climate of the original locality.

Genitalia preparations and preparations of larvae and pupae were essentially carried out as in the previous paper, but we did not slit the abdominal pelt, and as stains we used chlorazol black for females and sometimes male abdomens, and haemaluin according to Mayer for males and larvae, for some larvae phenosaffranin.

Measurements of genitalia and larvae were obtained from digital images, using AxioVision, $20 \times$ objective for male genitalia and usually $10 \times$ for females. DNA was extracted from caterpillars or from dry adult abdomens. DNA extraction from larvae was usually destructive; from abdomens and some larvae the non-destructive protocol by Knölke et al. (2005) was followed, allowing the preparation of the genitalia or larval skin as well. Details of methods are presented by Van Nieukerken et al. (2011), we provide here the COI DNA barcode for two species, details can be found on the Barcode of Life webpages (http://www.barcodinglife.com/views/ login.php) under the project "Pectinivalvinae Public records".

Photographs of moths, leafmines and microscope slides (genitalia, larvae, pupae) were taken with a Zeiss AxioCam (HR or MR5) digital camera attached respectively to a Zeiss Stemi SV11 stereomicroscope and a Zeiss Axioskop H, using Carl Zeiss AxioVision software (version 4). Manipulation of photographs, using Adobe Photoshop ${ }^{\oplus}$ was kept to a minimum: disturbing conspicuous shades, protruding parts of pins, dust and air bubbles in slides were removed or obscured.

Hostplants were identified with Harden et al. (2006) or Williams et al. (1984).

\section{Roscidotoga lamingtonia sp. $\mathbf{n}$.}

Figs 1-18, 20, 22, 23, 26

Type material. Holotype $\delta$ : Australia (Queensland), Lamington NP, Border Track to Tullawallal, UTM: 56J NP188794, 800-940 m, 19.viii.2004, leafmines on Sloanea woollsii, rainforest, emerged 11.x.2004, E.J. van Nieukerken \& R.J.B. Hoare, RMNH/EvN no 2004097, Genitalia slide EvN 3735, ANIC no. 18719, DNA extracted (ANIC).

Paratypes: $2 \hat{0}, 1$ . Australia (Queensland): $1 \delta$, Lamington NP, Daves Creek Circuit W. of
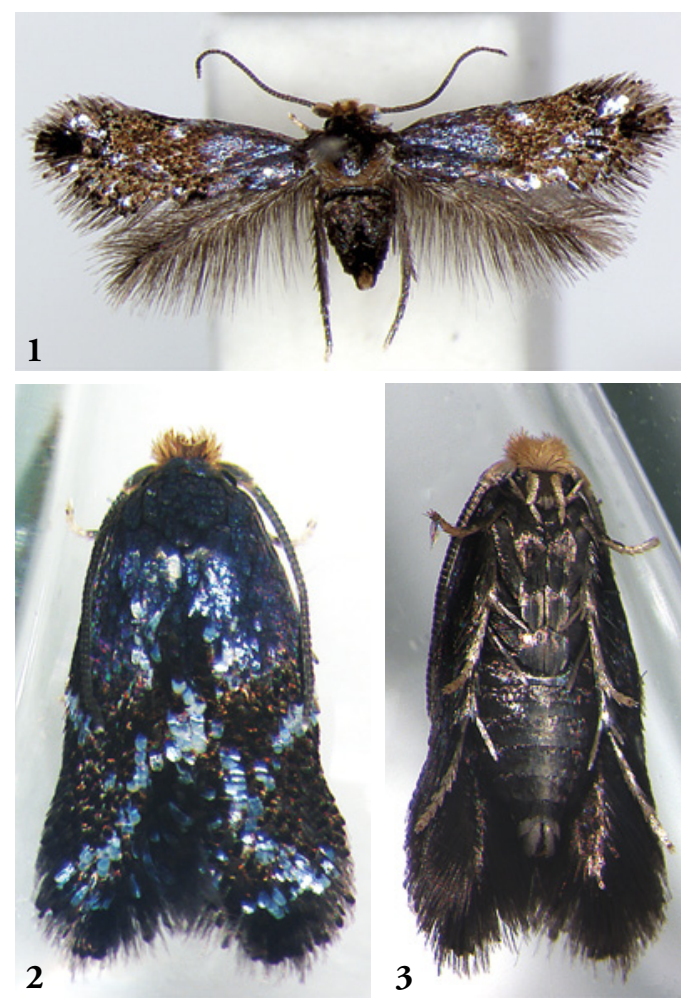

Figs 1-3. Roscidotoga lamingtonia, male holotype habitus. 1, Set specimen; 2, 3, Live specimen just after emergence.

Surprise Rock, UTM: 56J NP202785, 830 m, 12.viii. 2004, leafmines on Sloanea woollsii, dry rainforest, emerged 3.x.2004, E.J. van Nieukerken, RMNH/ $\mathrm{EvN}$ no $2004082(\mathrm{RMNH}) ; 10 \hat{0}, 19$ full grown dead pupae with complete adults inside, Lamington Nat. Pk, Daves Ck. Circuit, 28.13S-153.12E, 8.vii.2000, reared from leafmines on Sloanea woollsii, pupae recovered 9.iii.2001, R.J.B. Hoare \& C. van den Berg, genitalia slides CvdB077 (ઠ)), CvdB124 ( ) $)(\mathrm{RMNH})$.

Non type material. Australia (New South Wales): 1 Larva on slide, Border Ra. Nat. Pk. Palm Forest Wk.

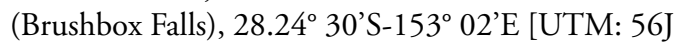
NP0357], 13.vii.2000, leafmines on Sloanea woollsii, R.J.B. Hoare \& C. van den Berg, larval preparation EvN 3528, DNA extracted (RMNH.INS.23528). Australia (Queensland): Leafmines from EvN samples 2004082 and 2004097 (type locality) (RMNH, ANIC), 1 larva from 2004082, destructively extracted for DNA (RMNH.INS.11835); Australia (New South Wales): Leafmines studied from Border Ranges NP. 

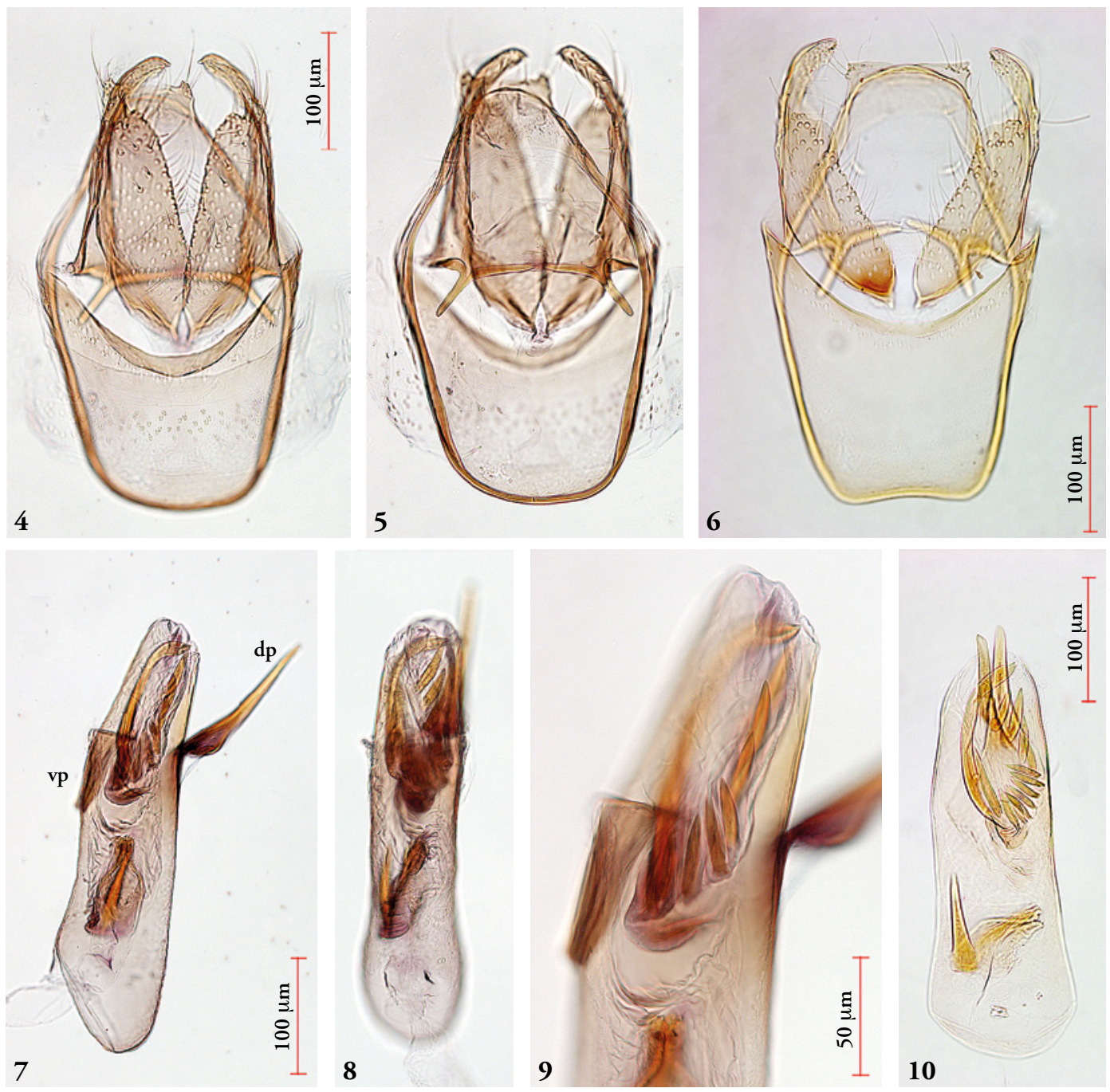

Figs 4-10. Roscidotoga lamingtonia, male genitalia, holotype, slide ANIC 18719 (4, 5, 7-9); paratype slide CvdB077 $(6,10) .4-6$, genitalia capsule; $7-10$, aedeagus, 8 , photographed in glycerine; $\mathrm{dp}=$ dorsal process; $\mathrm{vp}=$ ventral process.

\section{Diagnosis}

Roscidotoga lamingtonia most closely resembles $R$. callicomae, but it also has some similarities to $R$. sapphiripes, the edged scape, metallic collar with lamellate scales and bluish metallic thorax and forewing base are characteristic in combination. The male genitalia also resemble $R$. callicomae, but are easily separated by the larger number of cornuti and the long unforked dorsal process on the aedeagus. $R$. eucryphiae also has more cornuti (17), which are arranged in a U-shape; the cornuti are of even size, unlike in $R$. lamingtonia, and a cornutus associated with the base of the ejaculatory duct is lacking.
The valva in $R$. eucryphiae also differs in having the digitate process more humped laterally, and not extending beyond the tegumen / uncus. The female genitalia differ from $R$. callicomae and $R$. eucryphiae by the larger number of convolutions in the ductus spermathecae and the larger number of setae on T8.

\section{Description}

Male (Figs 1-3). Forewing length 2.1-2.3 mm (holotype 2.3), wingspan 5.0-5.1 mm. Live moth in rest slightly bell-shaped (Fig. 2). Head: frontal tuft entirely yellowish orange, or two lateral tufts on vertex darker, brownish; collar comprising lamellar 


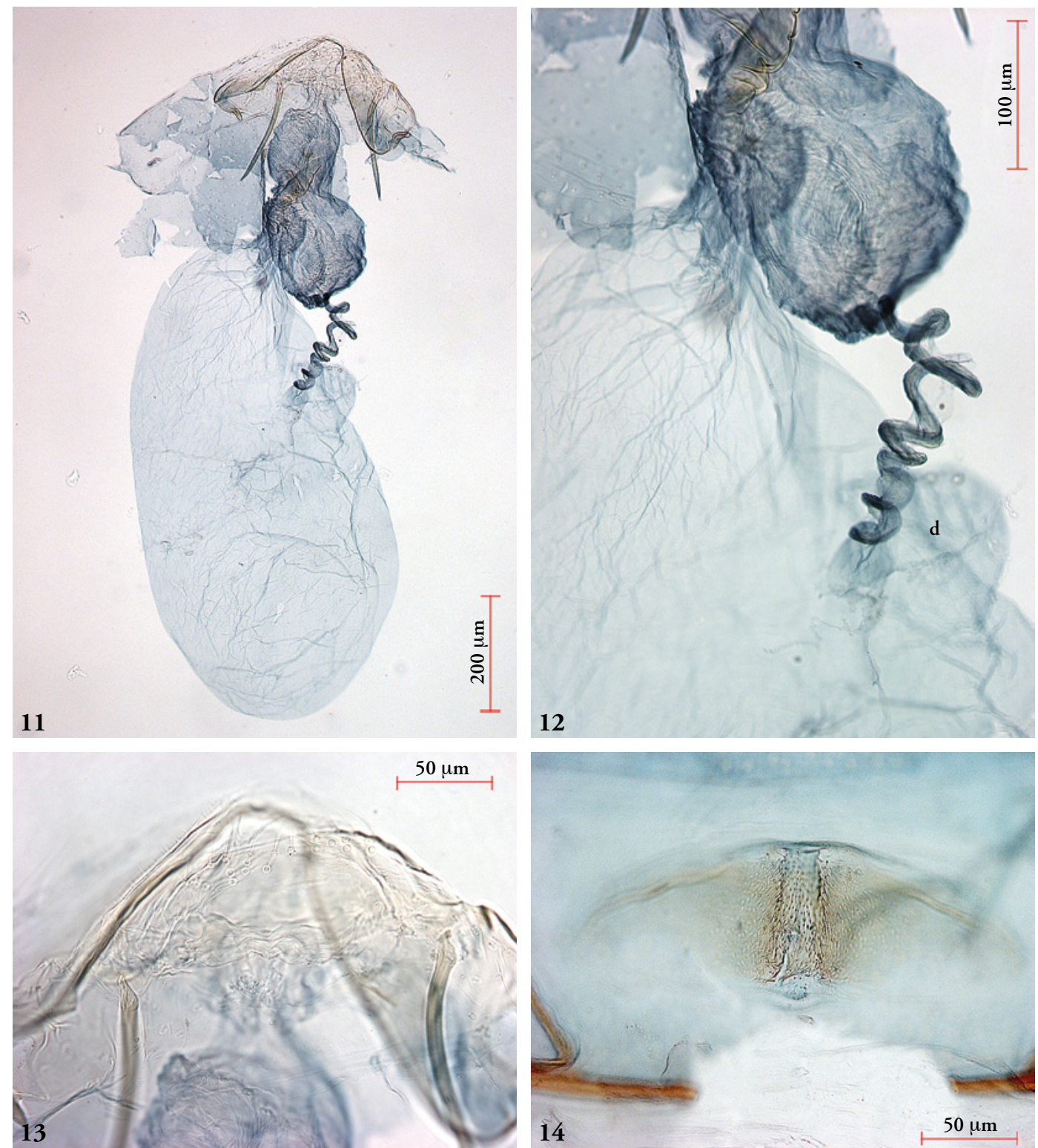

Figs 11-13. Roscidotoga lamingtonia, female genitalia, paratype, slide CvdB124 (11-13), with details of acessory sac, ductus spermathecae and diverticulum (=d) (12) and terminal segments (13). 14 Abdominal segment 2, male holotype.

scales, bluish metallic; antenna with 33-36 segments (holotype 36), scape large, longer than width of vertex between antennae, cream white, posterior third grey; flagellum grey brown. Thorax bluish metallic; forewing dark fuscous, basal third bluish metallic; silver metallic scales with bluish reflections scattered in distal two thirds, forming a triangular oblique streak from costa near middle slightly vari- able in size, and a very small to almost absent opposite dorsal spot; extent of silver markings variable; cilia line present. Hindwing and cilia grey brown; underside of both wings dark fuscous.

Abdomen upperside fuscous, almost black, no visible anal tufts; underside paler, silvery grey.

Male genitalia (Figs 4-10). Capsule 350-365 $\mu \mathrm{m}$ long. Vinculum with large ventral plate, slightly or 

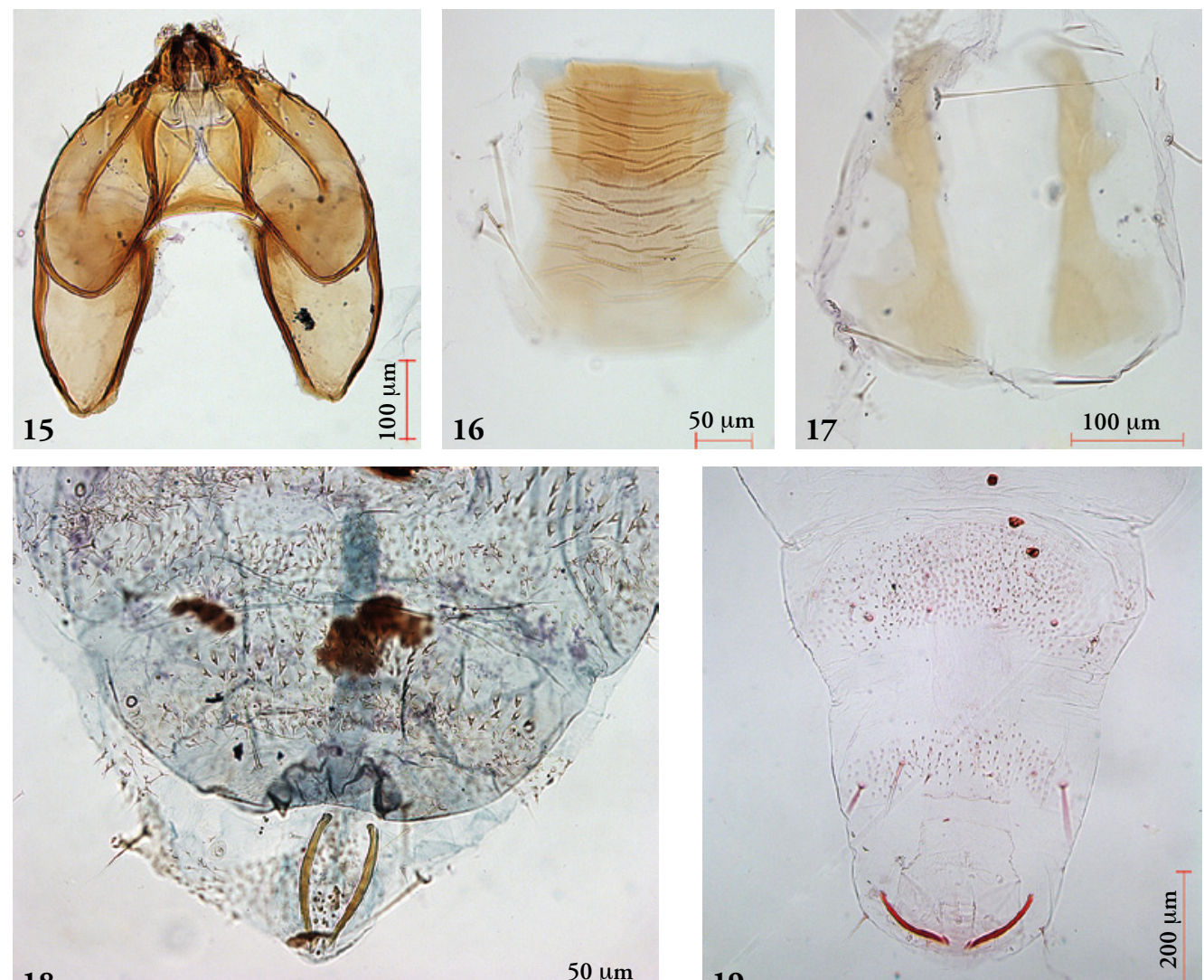

18

$50 \mu \mathrm{m}$

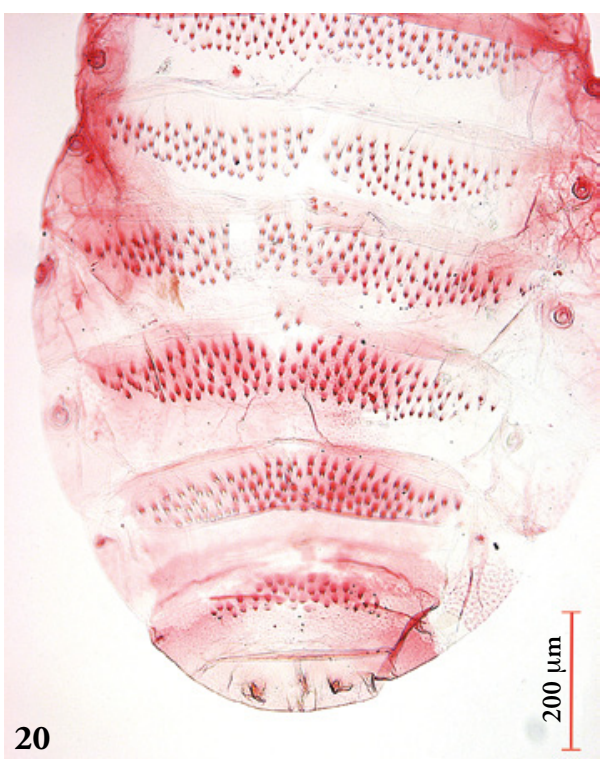

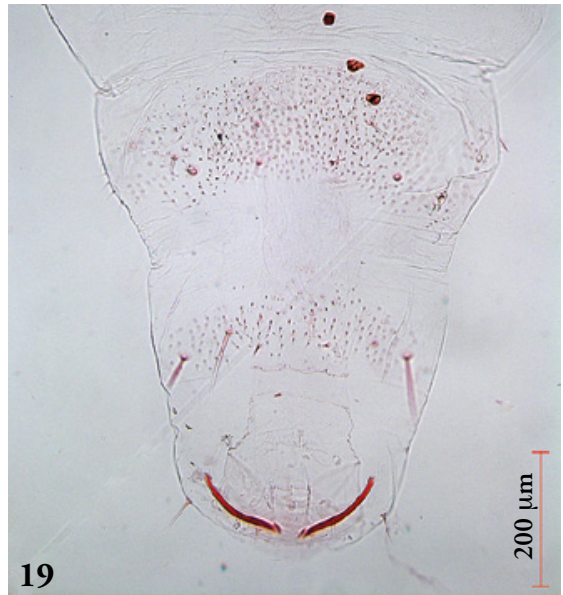

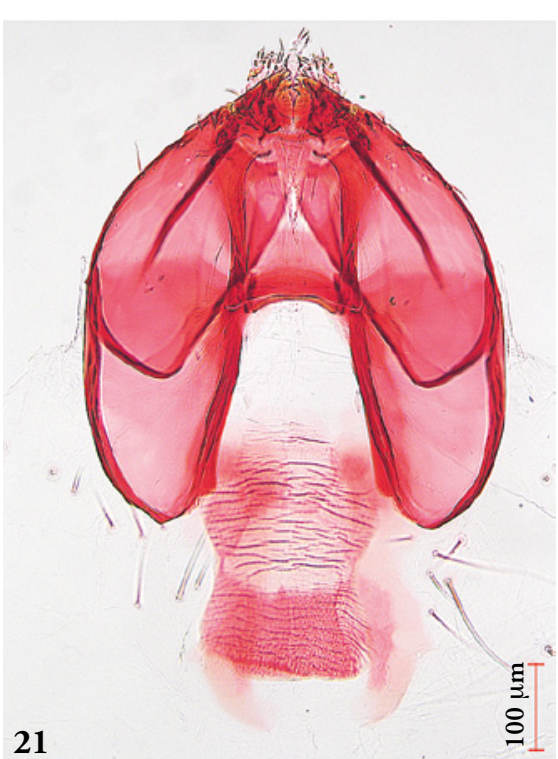

Figs 15-21. Roscidotoga, morphology of immatures. 15-18, 20, R. lamingtonia, slide EvN 3528 (larva) and CvdB124 (pupa); 19, 21, R. callicomae. 15, headcapsule; 16, sternite of prothorax; 17, tergites of prothorax; 18, 19 , last abdominal segments showing anal rods and microtrichia, pupal skin visible inside the larval integument; 20, pupal skin, abdominal tergites; 21 , head capsule and prothorax. 

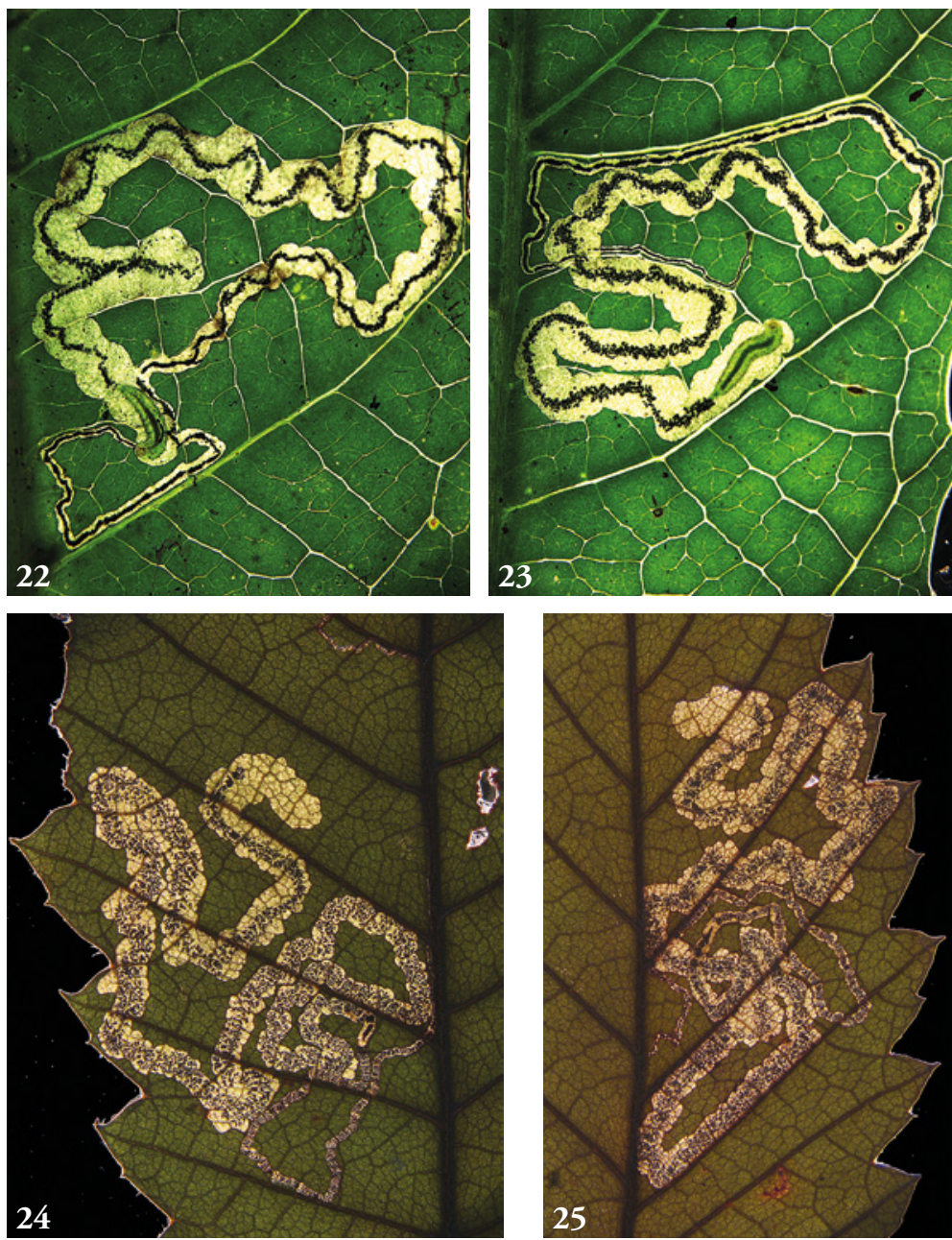

Figs 22-25. Roscidotoga, larval leafmines. 22, 23, $R$. lamingtonia, live larvae, type locality, EJvN2004097; 24, 25, $R$. callicomae, dried mines, Lamington NP, EJvN2004078. not indented. Tegumen/uncus with two widely separated posterior processes, each slightly serrate, with ca. 4 strong setae, in addition 2 strong setae dorsally on tegumen. Valva $205-250 \mu \mathrm{m}$ long, basally broadly triangular, narrowing towards two thirds, ending in a setose digitate process; transtilla interrupted in middle, sublateral processes rather long. Aedeagus 325-380 $\mu \mathrm{m}$ long, with long pointed dorsal process (dp in Fig. 7) and short triangular ventral process (vp in Fig. 7), in situ between valvae; vesica with one spine-like cornutus near base of ejaculatory duct, associated with indistinct sclerotization; distally one long curved cornutus (130-145 $\mu \mathrm{m}$ long) with thickened and split apex, next to a group of 9-11 dagger shaped cornuti of variable size.

Female genitalia (from pupa) (Figs 11-13). Total length ca $1000 \mu \mathrm{m}$. S8 broadly rounded. T8 a narrow rounded band with ca. 22 setae in total. Anterior apophyses with broadly lobed bases, with very short anterior apodemes, posterior apophyses narrow, rather long. Vestibulum with some indistinct sclerotizations, ending in small folded accessory sac of about $200 \mu \mathrm{m}$ long. Ductus spermathecae with ca. 6 convolutions. Corpus bursae with small diverticulum (d in Fig. 12), otherwise completely without structures.

Larva (Figs 15-18, 22, 23). Green, head pale brown, feeding with ventral side up. Headcapsule ca $440 \mu \mathrm{m}$ long, $445 \mu \mathrm{m}$ wide. A10 with 4 pairs of setae. Larva agrees otherwise with generic description, as far as could be judged. The single larva was taken from a cocoon and many characters are obscured by the presence of a pupal skin inside the larval integument (see Fig. 18).

Pupa (Fig. 20). Abdominal segments $2-8$ each with 4-5 rows of rather small spines, as in $R$. callicomae. 


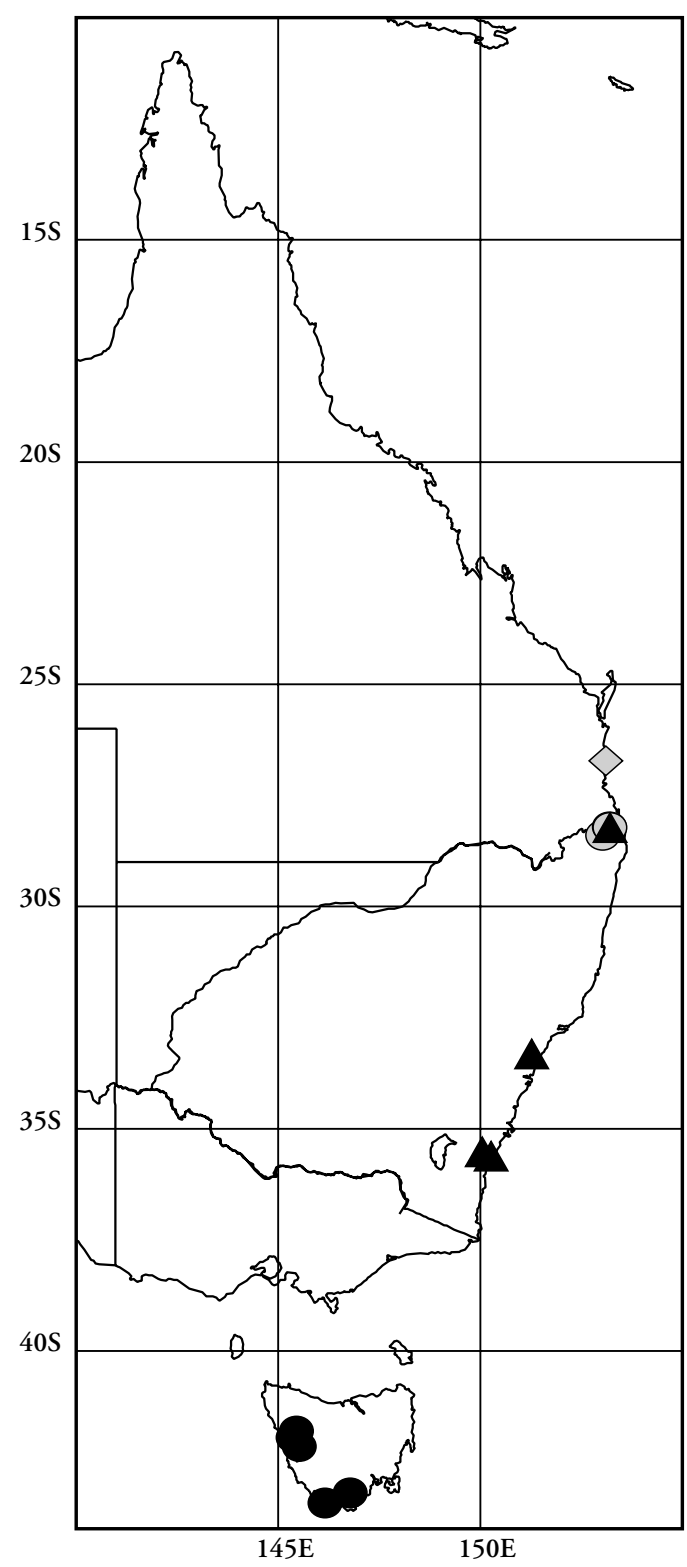

Fig. 26. Distribution of Roscidotoga. Triangles: $R$. callicomae; black dots: $R$. eucryphiae, grey dots: $R$. lamingtonia, diamond: $R$. sapphiripes.

\section{Biology}

Host plant. Sloanea woollsii F. Muell. (Elaeocarpaceae), a tree of warm temperate and subtropical rainforest, common in coastal NSW and Queensland.

Egg. On either surface of leaf, in 12 out of 28 mines on upper surface, usually against a vein.
Mine (Figs 22, 23). A more or less contorted linear gallery with linear frass throughout, later slightly dispersed, but still leaving broad margins; exit-hole on upperside. Cocoon: brown.

Larvae were collected on 8 and 13 July and 12 and 19 August; adults emerged indoors (in The Netherlands!) on 3 and 11 October.

\section{Distribution (Fig. 26)}

Australia: southern Queensland and northern New South Wales, McPherson Range.

\section{DNA barcode}

Genbank accession numbers: JN640296 (holotype), JN640295 (RMNH.INS.11835), JN640297 (RMNH.INS.23528). The three sequences were $100 \%$ identical.

\section{Remarks}

Within Lamington National Park, Sloanea woollsii is a widespread and common tree in warm temperate and subtropical rainforest, and also $R$. lamingtonia appears to be rather common. We found mines on several sites along the Lower Bellbird, Border Track and Daves Creek Circuits, ranging from about $500 \mathrm{~m}$ to $840 \mathrm{~m}$ in altitude.

\section{Etymology}

The epithet lamingtonia a feminine adjective, is derived from the moth's type locality, Lamington National Park.

\section{Roscidotoga callicomae Hoare}

Figs 19, 21, 24-26

Roscidotoga callicomae Hoare 2000: 295. Holotype ô, Australia (NSW): $1 \mathrm{~km}$ SE of East Lynne, Kioloa State Forest, emg. 29.xi.1995, R. J. B. Hoare. Genitalia slide 13610 (ANIC).

Material. Australia (Queensland): 2 larvae on slide, many leafmines, Lamington NP, Picnic Creek crossing Daves Creek Circuit, 750 m, 12.viii.2004, Callicoma serratifolia, open woodland, mallee, E.J. van Nieukerken, EJvN2004078, RMNH.INS.12424 (RMNH); 2 larvae, ditto, extracted destructively, RMNH.INS.11833 and 11834 (extracts in RMNH).

We record $R$. callicomae here for the first time from Queensland based on the record of mines and larvae alone: no adults were reared. The mines and larvae completely agree with the original description. The mines (Figs 24, 25) have typically coiled frass and 
the egg was always on leaf upperside. The larva is illustrated in Figs 19 and 21.

\section{DNA barcode}

Genbank accession numbers JN640293, JN640294. The two sequences from the Lamington Park differ only in one position. COI of the two species differs in 35 positions, $92 \%$ similarity.

\section{Discussion}

\section{Phylogeny}

The finding of a fourth species of Roscidotoga does not contradict any of the phylogenetic assumptions made based on the other three species (Hoare 2000). $R$. lamingtonia especially resembles $R$. callicomae in many characters, and shares all the listed apomorphies of the genus. The diverticulum of the female bursa is even better visible in our preparation than in those studied before.

For a phylogenetic analysis of the genus we have only few suitable characters available, but these still could be interpreted as apomorphies as follows:

1) Long distal curved cornutus present. This cornutus is present in $R$. lamingtonia and $R$. sapphiripes.

2) The presence of a cornutus or cornuti associated with the base of the ejaculatory duct groups lamingtonia with callicomae and sapphiripes to the exclusion of eucryphiae.

3) The short spines on the pupal abdomen may be another character grouping the three species except $R$. eucryphiae, but this is unknown for $R$. sapphiripes. Externally these three species also are more similar, giving extra support for a monophyletic clade of callicomae and the Elaeocarpaceae feeders.

\section{Host plant relationships}

$R$. lamingtonia is the second species of Roscidotoga known to feed on Elaeocarpaceae; $R$. sapphiripes was reared from Elaeocarpus obovatus (see Hoare 2000). The genus Sloanea is a large genus of trees ( ca 150 species), occurring in South America, Madagascar, throughout the Oriental region, and in Australia with four species. These are only known from the rainforest zone in New South Wales and Queensland. Since the discovery of Roscidotoga, more data have become available on the phylogeny of the hostplants, and Eucryphiaceae are (since 2000) regarded as a subgroup of the Cunoniaceae, which again are closely related to the Elaeocarpaceae in the order Oxalidales (APG II 2003, Crayn et al. 2006, Savolainen et al. 2000, Soltis et al. 2000, Soltis et al. 2005, APG III 2009). The monophagy of Roscidotoga on (a subgroup of) Oxalidales is therefore again confirmed. We assume that the genus will even be more widely distributed in Queensland, where almost no field work focussing on Nepticulidae has been done in the more northern rainforests. Because the genera Sloanea and Elaeaocarpus are widely distributed in the adjacent Oriental region, it is of course still possible that Roscidotoga will be discovered outside Australia, where Nepticulidae have hardly been studied. No Nepticulidae have been described from New Guinea, but the first adults, belonging to some species of Stigmella Schrank, 1802, have recently been reared (S. Miller, personal communication) and are currently under study by the senior author. We expect a rich fauna of Nepticulidae in New Guinea and other parts of Indonesia; fieldwork in Kalimantan by the senior author in 2005 has revealed a rich nepticulid fauna in the lowland dipterocarp rainforests.

In fact, a vacated nepticulid mine was found on a supposed leaf of Elaeocarpus in Vietnam (found on the ground), but without larva or adult, this mine cannot be attributed to any genus.

If the above suggested phylogeny is true, there has only been one hostshift from Cunoniaceae to Elaeocarpaceae. Co-speciation is implausible, since Roscidotoga species are closely related, whilst the hostplant families probably diverged in the Cretaceous. It is likely that the split between Roscidotoga and Pectinivalva took place in the rainforest environment before the Miocene desiccation of Australia, after which Pectinivalva radiated in the dry Eucalyptus forests.

\section{Acknowledgements}

We are grateful to Marianne Horak (ANIC, Canberra) for support and facilitating the export of specimens from Australia. The Queensland Parks and Wildlife Service and NSW parks are acknowledged for permission to collect in the parks. We thank Dick Groenenberg and Camiel Doorenweerd (NCB Naturalis Leiden) for molecular work. Marianne Horak and Don Davis are acknowledged for reviewing the manuscript.

\section{References}

APG II, 2003. An update of the Angiosperm Phylogeny Group classification for the orders and families of flowering plants: APG II. - Botanical Journal of the Linnean Society 141 (4): 399-436. Doi: 10.1046/ j.1095-8339.2003.t01-1-00158.x

APG III, 2009. An update of the Angiosperm Phylogeny Group classification for the orders and families of 
flowering plants: APG III. - Botanical Journal of the Linnean Society 161 (2): 105-121. Doi: 10.1111/j.1095-8339.2009.00996.x

Crayn, D.M., M. Rossetto \& D.J. Maynard, 2006. Molecular phylogeny and dating reveals an Oligo-Miocene radiation of dry-adapted shrubs (former Tremandraceae) from rainforest tree progenitors (Elaeocarpaceae) in Australia. - American Journal of Botany 93 (9): 1328. Doi: 10.3732/ajb.93.9.1328

Harden, G.J., J.B. Williams \& W.J.F.B. McDonald, 2006. Rainforest trees and shrubs. A field guide to their identification. - Gwen Harden Publishing, Nambucca Heads, N.S.W. 264 pp.

Hoare, R.J.B., 2000. A new genus of primitive Nepticulidae (Lepidoptera) from eastern Australia, with a revised diagnosis of nepticulid subfamilies. - Zoological Journal of the Linnean Society 128 (3): 289-317. Doi:10.1006/zjls.1998.0189

Knölke, S., S. Erlacher, A. Hausmann, M.A. Miller \& A.H. Segerer, 2005. A procedure for combined genitalia dissection and DNA extraction in Lepidoptera. - Insect Systematics and Evolution 35 (4): 401-409. Doi: $10.1163 / 187631204788912463$

Nieukerken, E.J. van, C. Doorenweerd, F.R. Stokvis \& D.S.J. Groenenberg, 2011. DNA barcoding of the leaf-mining moth subgenus Ectoedemia s. str. (Lepidoptera: Nepticulidae), by COI and EF1- $\alpha$ : two are better than one in recognising cryptic species - Contributions to Zoology 81: in press.
Savolainen, V., M.W. Chase, S.B. Hoot, C.M. Morton, D.E. Soltis, C. Bayer, M.F. Fay, A.Y. De Bruijn, S. Sullivan \& Y.L. Qiu, 2000. Phylogenetics of flowering plants based on combined analysis of plastid atpB and rbcL gene sequences. - Systematic Biology 49 (2): 306-362. Doi: 10.1093/sysbio/49.2.306

Soltis, D.E., P.S. Soltis, M.W. Chase, M.E. Mort, D.C. Albach, M. Zanis, V. Savolainen, W.H. Hahn, S.B. Hoot, M.F. Fay, M. Axtell, S.M. Swensen, L.M. Prince, W.J. Kress, K.C. Nixon \& J.S. Farris, 2000. Angiosperm phylogeny inferred from $18 \mathrm{~S}$ rDNA, $r b c L$, and $a t p B$ sequences. - Botanical Journal of the Linnean Society 133 (4): 381-461.

Soltis, D. E., P. S. Soltis, P. K. Endress \& M. W. Chase, 2005. Phylogeny and evolution of Angiosperms. - Sinauer Ass., Sunderland, Massachusetts. 370 pp.

Williams, J. B., G. J. Harden \& W. J. F. McDonald, 1984. Trees \& shrubs in rainforests of New South Wales and southern Queensland. - Botany Department, University of New England, Armidale. 142 pp.

Received: 18 August 2011

Accepted: 31 August 2011 


\section{Book reviews}

Noordijk, J., R.M.J.C. Kleukers, E.J. van Nieukerken \& A.J. van Loon (editors), 2010. De Nederlandse Biodiversiteit [Biodiversity of the Netherlands]. Nederlandse Fauna 10, Netherlands Centre for Biodiversity Naturalis \& European Invertebrate Survey - Nederland, Leiden. ISBN 978905011351 9, hardcover, 512 pp. Price € 49.95 (excl. p\&p), order at http://www. knnvuitgeverij.nl/EN. In Dutch, English summary.

2010 was a memorable year for biodiversity. It was declared International Year of Biodiversity by the United Nations, and worldwide actions were promoted under the United Nations Environment Programme. In The Netherlands the year had a special meaning. The Internationaal Jaar van de Biodiversiteit was launched on January 28 in Leiden together with the official start of the Netherlands Centre for Biodiversity Naturalis (NCB Naturalis), a merger of the National Museum of Natural History Naturalis (Leiden), the Zoological Museum Amsterdam and the National Herbarium Nederland. At the occasion this unique book was presented, published by NCB Naturalis together with European Invertebrate Survey Nederland, an organization linked to NCB Naturalis.

It is hard to describe the book without falling into superlatives. It is an update of the book Biodiversiteit in Nederland, published in 1995 by the then National Museum of Natural History (Leiden) and KNNV publishers. But to call it just an update does not do justice to this book. The wealth of information in the 510 pages is incredible. After introductory chapters (covering the first 47 pages of text) on how biodiversity has developed since early life, on how biodiversity is studied (a very instructive chapter of 24 pages), and on evolution and classification, the bulk of the book (chapter 5, 249 pages) is a description of the biodiversity in The Netherlands. The text was written by about 100 authors. It must have been an immense task for the editors to fit all contributions into the same template. Throughout, cladograms are given indicating interrelationships of taxa at various levels. For all groups treated, be it at the level of phylum, classis, order or family, information is given on life cycle, ecology, diversity (worldwide and in The Netherlands) and occurrence in The Netherlands, and references are given for identification. For the number of species two categories have been distinguished: settled (meaning

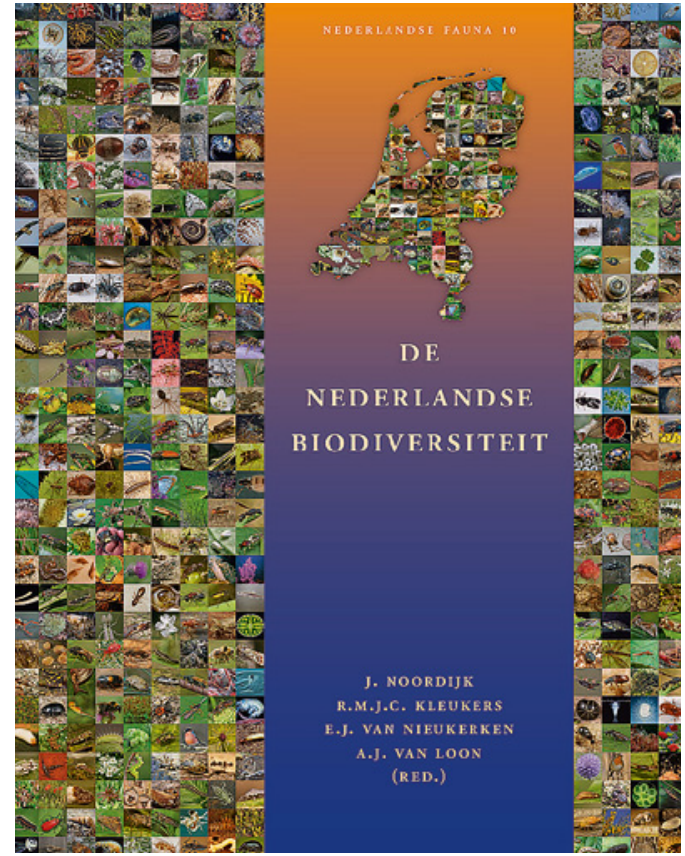

that the species has lived here for at least ten years consecutively without the aid of men, whether their origin is indigenous or alien) and not settled. The number of settled species has been given for families in a number of larger groups, such as vascular plants, birds, beetles, Lepidoptera, and Hymenoptera (with 5315 settled species by far the largest order of animals in The Netherlands) to the level of family. In other cases the number of species is given for higher categories, rarely for lower categories. The number of species with an alien origin (exotic species) among the settled species is stated, as is the number of species to be expected in The Netherlands.

The total number of organisms for The Netherlands is summed up in chapter 6 ( 15 pages). It amounts to ca. 47,800 species (among which are ca. 1100 exotic species). Since most people, when asked about biodiversity, think of birds, mammals, flowers and other conspicuous groups like butterflies and dragonflies, altogether some 2000 species, such a high number may come as a surprise. A large part of the biodiversity ( $15 \%$, some 7000 species) is invisible to the naked eye, being unicellular organisms. Undoubtedly we know these organisms very imperfectly. Of the most primitive group, Eubacteria, there are ca. 1000 species known in the Netherlands, but thousands may still go undetected. continued on page 214 